\title{
Perancangan Aplikasi Nilai Siswa Pada Sekolah Dasar Negeri 23 Palembang
}

\author{
Mariana Purba \\ Politeknik Anika, Jln. Jend Sudirman No.3010 B Palembang \\ Program Studi Manajemen Informatika \\ purbamariana@yahoo.co.id
}

\begin{abstract}
Abstrak- Penelitian ini bertujuan dapat membantu pekerjaan setiap pegawai yang membutuhkan data siswa, data mata pelajaran, dan data nilai siswa pada Sekolah Dasar Negeri 23 Palembang dimana pada Sekolah Dasar Negeri 23 Palembang penyampaian informasi yang berhubungan dengan kegiatan belajar mengajar masih dilakukan sederhana. Ini terlihat dari masih menggunakan kertas dan kalkulator dalam menghitung nilai siswa. Sistem nilai yang berjalan di Sekolah ini dalam proses penyampaian informasi pembuatan nilai akhir rapor masih dilakukan secara manual. Proses-proses tersebut mempunyai kerumitan tersendiri terkait dengan fasilitas yang tersedia. Hal ini juga menimbulkan berbagai permasalahan lainnya seperti proses penyampaian laporan yang tidak tepat waktu, serta pencarian data yang membutuhkan waktu lama. Hal ini pun menyulitkan Guru dalam memberikan laporan kepada kepala sekolah. Dengan adanya aplikasi menngunakan bahasa permrograman microsoft visual basic dan database access data nilai siswa ini diharapkan dapat membantu sekolah dalam mempercepat rekap hasil nilai siswa dan pembuatan terhadap backup file-file yang penting bagi sekolah sebaiknya dilakukan setiap akhir bulan dan mengingat perkembangan zaman yang semakin hari semakin berkembang terutama dibidang teknologi yang membantu aktivitas disegala bidang terutama bidang pendidikan, sebaiknya sekolah jangan sampai ketinggalan arus teknologi tersebut dalam membantu pembangunan nasional.
\end{abstract}

Kata Kunci-Microsoft Visual Basic, Microsoft Access, File

\section{Pendahuluan}

Teknologi komputer dan informasi sekarang ini setiap tahunnya mengalami peningkatan dan kualitas yang sangat baik, mendorong timbulnya akan informasi komputer disegala bidang. Salah satu informasi yang penting dalam dunia pendidikan adalah tentang bagaimana siswa mampu mematuhi setiap peraturan yang ditetapkan sekolah, mampu bersosialisasi dengan setiap guru dan menjadi siswa yang mampu memahami visi dan misi sekolah, informasi penting juga dalam menetapkan serta melengkapi data guru tersebut, mulai dari pangkat, jabatan, dan cuti sekolah. Pengolahan informasi memang dapat dilakukan secara manual, namun karena setiap manusia memiliki kekurangan serta keterbatasan dalam setiap pemahamannya sehingga menjadikan setiap pekerjaan yang dilakukan secara manual menjadi terbatas dan lambat prosesnya dan bahkan dapat terjadi suatu kesalahan yang besar.
Salah satu yang memanfaatkan kemajuan teknologi tersebut adalah bidang pendidikan. Teknologi komputer tidak hanya digunakan dalam hal belajar mengajar, yaitu Sekolah Dasar Negeri 23 Palembang beralamat di Jl. Bidar No.7, RT.22, Lorok Pakjo, Ilir Bar. I, Kota Palembang, Sumatera Selatan 30137merupakan salah satu sekolah milik pemerinta yang ada di Palembang di bawah naungan Dinas Pendidikan yang telah berdiri sejak tahun 1997. Adapun prosedur yang dilakukan adalah meliputi penghitungan nilai. . Meski pada kenyataannya komputer hanya digunakan untuk membuat laporan yang tidak menutup kemungkinan terjadinya kesalahan yang disebabkan oleh sifat alami manusia, ketidak pahaman dalam pengolahan data dikarenakan data yang disimpan masih berupa dokumen. Dokumen kemungkinan bisa hilang karena kesalahan dalam penyimpanan dan sebagainya. Di Sekolah Dasar Negeri 23 palembang penyampaian informasi yang berhubungan dengan kegiatan belajar mengajar masih dilakukan sederhana. Ini terlihat dari masih menggunakan kertas dan kalkulator dalam menghitung nilai siswa. Sistem Akademik yang berjalan di Sekolah ini, dalam proses penyampaian informasi pembuatan nilai akhir rapor masih dilakukan secara manual. Proses- proses tersebut mempunyai kerumitan tersendiri terkait dengan fasilitas yang tersedia. Hal ini juga menimbulkan berbagai permasalahan lainnya seperti proses penyampaian laporan yang tidak tepat waktu, serta pencarian data yang membutuhkan waktu lama. Hal ini pun menyulitkan Staff Pengajar dalam memberikan laporan kepada kepala sekolah

Oleh karena itu, dengan adanya sebuah aplikasi nilai siswa ini peneliti mengharapkan akan membantu mengatasi permasalahan yang selama initerjadi pada sekolah dasar negeri 23 palembang ini sehingga proses belajar mengajar yang sedang terjadi dapat lebih mudah antara lain pencarian data siswa, data guru data mata pelajaran dan nilai siswaakan lebih mudah diinput kemudian diproses sehingga guru akan lebih cepat menyelesaikan tugasnyauntuk mengisi nilai rapot dan memberikan laporannya kepada kepala sekolah.

\section{LANDASAN TEORI}

\section{A. Perancangan}

Perancangan menurut Al-Bahra Bin Ladjamudin (2005:39) dalam bukunya yang berjudul Analisis dan Desain Sistem 
Informasi, adalah sebagai berikut: "Tahapan perancangan (design) memiliki tujuan untuk mendesain sistem baru yang dapat menyelesaikan masalah-masalah yang dihadapi perusahaan yang diperoleh dari pemilihan alternatif sistem yang terbaik".

\section{B. Basis Data}

Basis data terdiri atas dua kata, yaitu basis dan data. Basis kurang lebih dapat diartikan sebagai markas atau gudang, tempat bersarang /berkumpul. Sedangkan data adalah representasi fakta dunia nyata yang mewakili suatu objek seperti manusia, (pegawai, siswa, pembeli, pelanggan), barang, hewan, peristiwa, konsep, keadaan, dan sebagainya, yang diwujudkan dalam bentuk angka, huruf, simbol, teks, gambar, bunyi, atau kombinasinya. Sebagai satu kesatuan istilah, basis data (database) sendiri dapat didefinisikan dalam sejumlah sudut pandang seperti:

- Himpunan kelompok data (arsip) yang saling berhubungan yang diorganisasi sedemikian rupa agar kelak dapat dimanfaatkan kembali dengan cepat dan mudah.

- Kumpulan data yang saling berhubungan yang disimpan secara bersama-sama sedemikian rupa dan tanpa pengulangan (redudansi) yang tidak perlu, untuk memenuhi berbagai kebutuhan.

- Kumpulan file/tabel/arsip yang saling berhubungan yang disimpan dalam media penyimpanan elektronis. (Fathansyah, 2012 : 2-3) Istilah basis data dapat dipahami sebagai suatu kumpulan data terhubung (interrelated data) yang disimpan secara bersama-sama pada suatu media, tanpa mengatap satu sama lain atau tidak perlu suatu kerangkapan data (kalaupun ada maka kerangkapan data tersebut harus seminal mungkin dan terkontrol (controlled redundancy), data disimpan dengan cara-cara tertentu sehingga mudah digunakan / atau ditampilkan kembali; data dapat digunakan oleh satu atau lebih program-program aplikasi secara optimal; data disimpan tanpa mengalami keterangan dengan program yang akan menggunakannya; data disimpan sedemikian rupa sehingga proses penambahan, pengambilan, dan modifikasi data dapat dilakukan data dapat dilakukan dengan mudah dan terkontrol. (Sutanta, $2011: 29-30$ ).

\section{Pengertian Microsoft Visual Basic 6.0}

Menurut Arief Ramadhan (2005:3-4), Visual Basic 6.0 merupakan aplikasi pemrograman Visual yang dibuat oleh Microsoft. Visual Basic 6.0 berjalan dalam sistem operasi Windows visual Studio 6.0.

\section{Microsoft Access 2007}

Menurut Suarna (2008:05) Microsoft Acces 2007 adalah sebuah program aplikasi database, yaitu keluaran dari Microsoft Corporation yang dirancang khusus untuk pengelolaan database untuk semua program diantaranya adalah Visual Basic, Delphi, PHP, pemrograman berbasis web dan lain-lain.

\section{E. Crystal Report}

Crystal Report merupakan program yang terpisah dengan program Microsoft Visual Basic.NET tetapi keduanya dapat dihubungkan. Membuat laporan dengan Crystal Report hasilnya lebih baik dan lebih mudah, karena pada Crystal Report banyak tersedia objek-objek maupun komponen yang mudah digunakan. (ANDI:200:234).

\section{F. Nilai}

Menurut Jurnal Ruslan (2014) Nilai adalah salah satu bagian dari kegiatan belajar mengajar di sekolah, seringkali data nilai yang ada menjadi masalah tersendiri bagi guru, wali kelas dan siswa di sekolah. Repotnya sistem penilaian dan penyimpanan hasil nilai siswa menjadi faktor terbesar dalam masalah penilaian ini.

\section{Metodologi Penelitian}

\section{A. Metode Pengumpulan Data}

Untuk memperoleh data dan informasi yang diperlukan, maka pengumpulan data dan informasi dilakukan dengan cara sebagai berikut:

\section{1) Riset Lapangan}

Peneliti mendatangi langsung tempat pengambilan data pada Sekolah Dasar (SD) Negeri 23 Palembang yg beralamat di Jl. Bidar No.7, RT.22, Lorok Pakjo, Ilir Bar. I, Kota Palembang, Sumatera Selatan 30137.

\section{2) Riset Perpustakaan}

Peneliti membaca buku-buku panduan penelitian yang dapat membantu peneliti dalam menyelesaikan penelitian ini dan membaca buku-buku panduan yang berhubungan dengan materi yang dibahas.

\section{B. Teknik Pengumpulan Data}

\section{1) Interview atau Wawancara}

Yaitu peneliti melakukan wawancara atau tanya jawab dengan salah satu staf Sekolah Dasar (SD) Negeri 23 Palembang mengenai administrasi data guru,data siswa, data mata pelajaran dan data nilai siswa yang dapat memberikan informasi dan data yang kongkrit.

\section{2) Observasi}

Yaitu peneliti mengamati secara langsung bagaimana kegiatan belajar mengajar untuk melengkapi data-data yang dibutuhkan.

\section{Sumber Data}

\section{1) Data Primer}

Mengumpulkan data secara langsung dari objek yang diteliti. Data yang dibuat oleh peneliti untuk maksud menyelesaikan permasalahan yang sedang ditangani. Data 
yang dikumpulkan sendiri oleh peneliti langsung dari sumber pertama atau tempat objek penelitian dilakukan.

\section{2) Data Sekunder}

Data yang telah dikumpulkan untuk maksud selain menyelesaikan masalah yang sedang dihadapi. Data ini dapat ditemukan dengan cepat. Dalam penelitian ini yang menjadi sumber data sekunder adalah literatur, artikel, jurnal, serta situs di internet yang berkenaan dengan penelitian

D. Flowchart Pengolahan Data Yang Berjalan

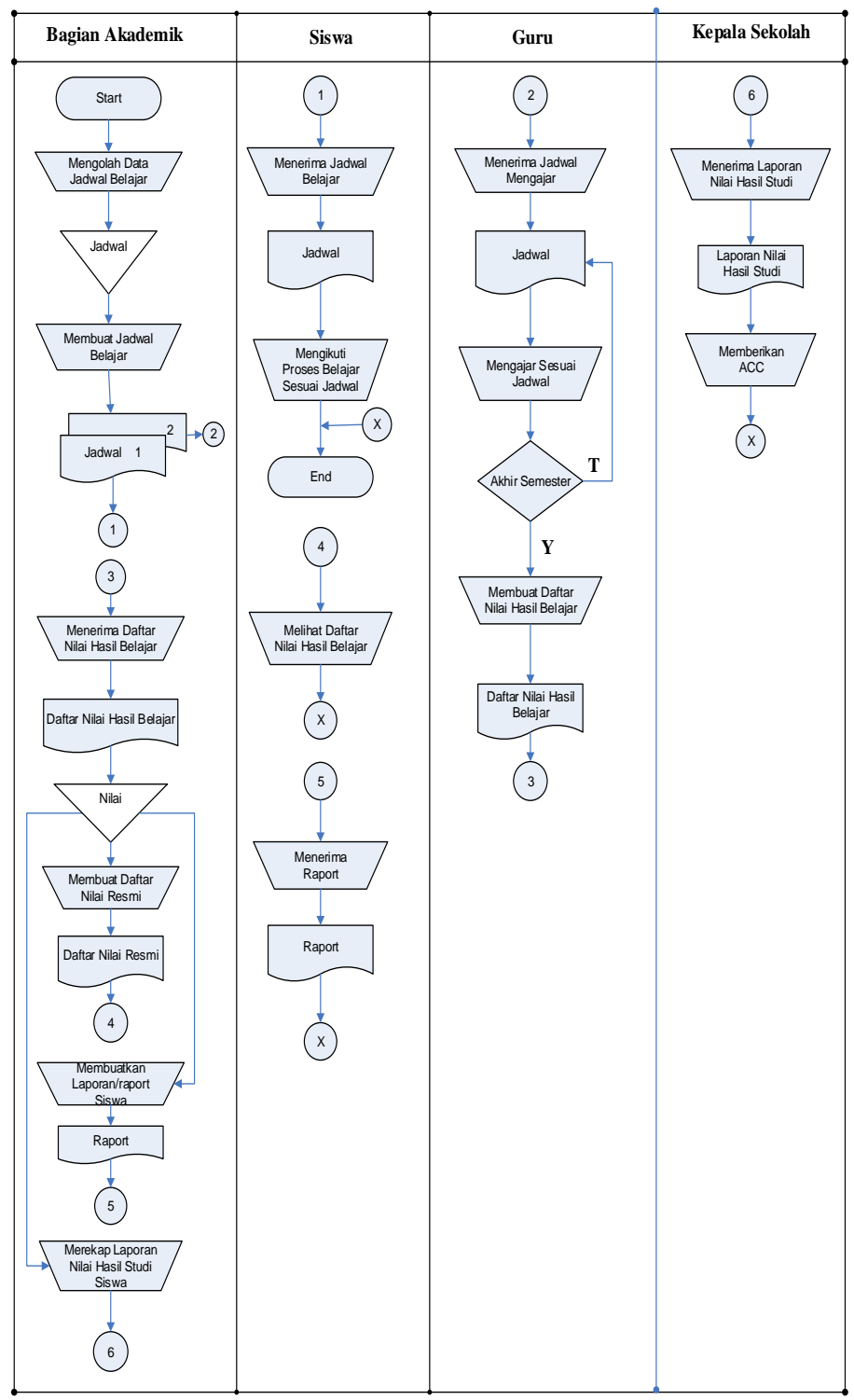

Gambar 1.flowchart pengolahan data yang berjalan
E. Data Flow Diagram (DFD)

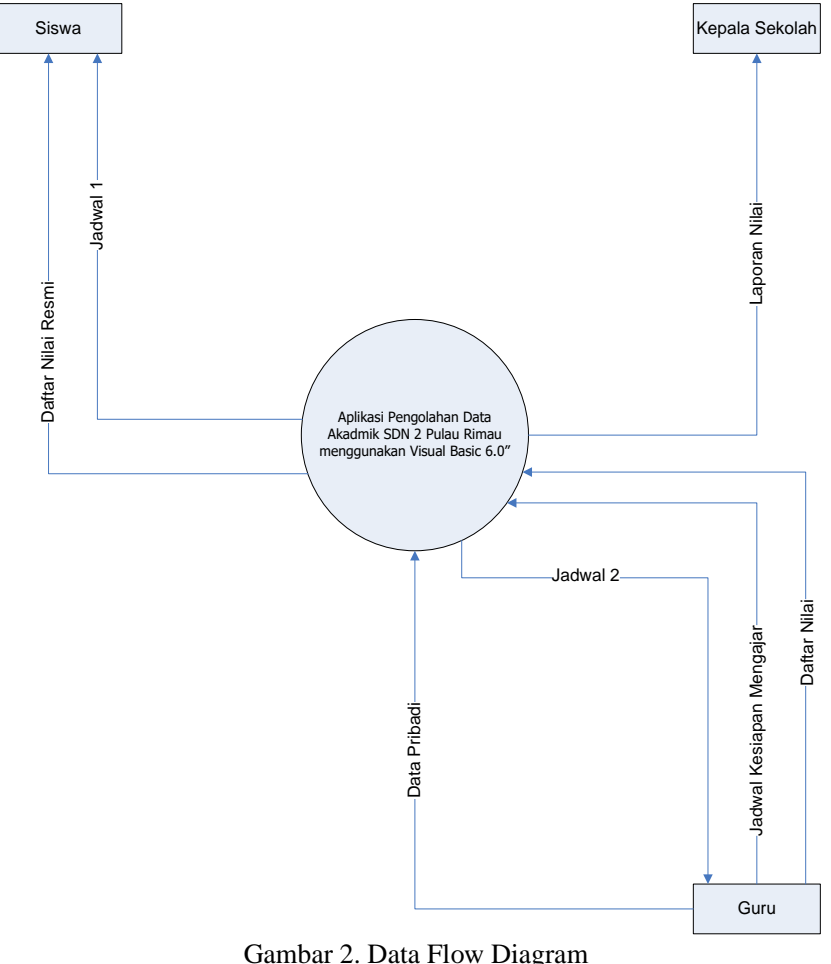

F. Entity Relation Diagram (ERD)

353 Endity Relationship Dhapran (ERD)

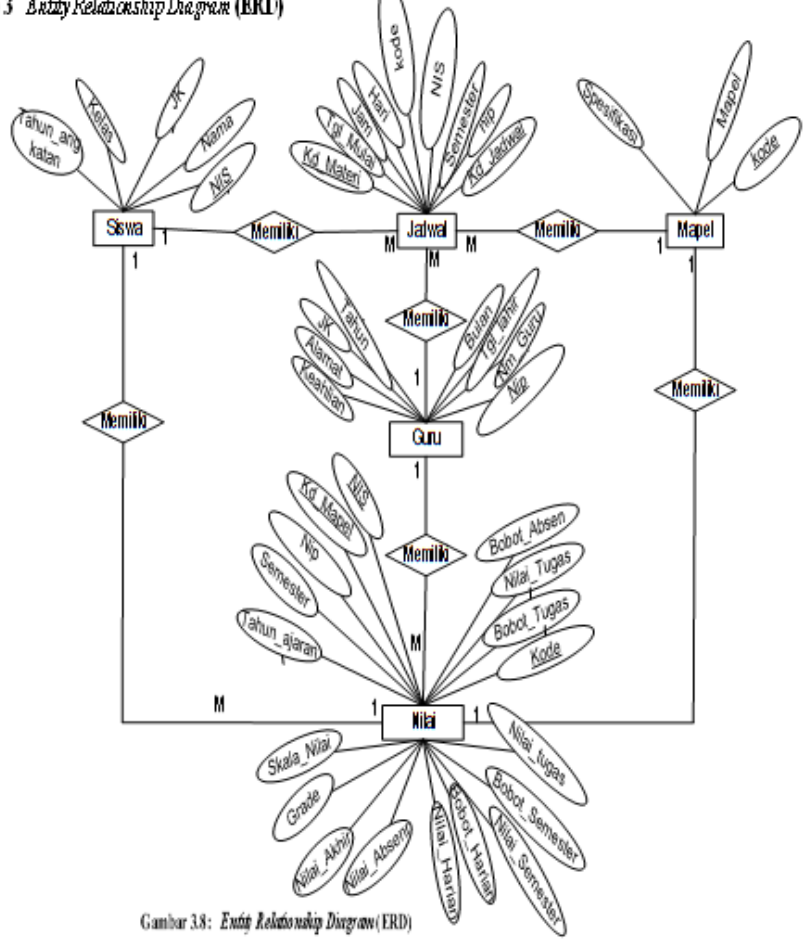

Gambar 3. Entity Relation Diagram (ERD) 


\section{HASIL DAN PEMBAHASAN}

\section{A. Tampilan Form}

\section{1) Tampilan Form Menu Utama}

Tampilan ini merupakan tampilan awal untuk menjalankan program nilai siswa.

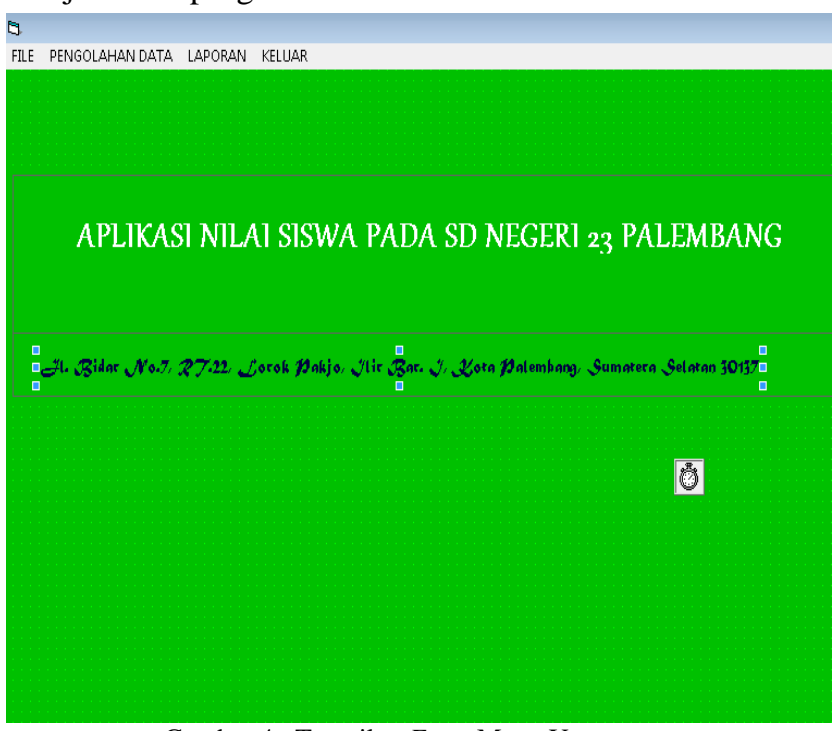

Gambar 4. Tampilan Form Menu Utama

\section{2) Tampilan Form Login}

Form login digunakan pada saat ingin menjalankan program dengan mengisi username dan password.

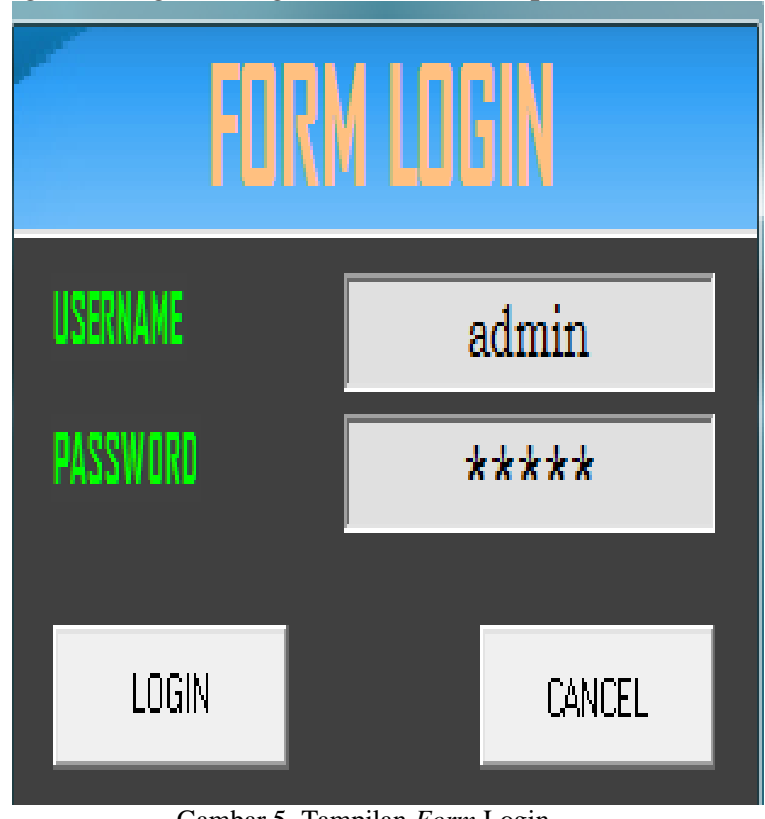

Gambar 5. Tampilan Form Login

\section{3) Tampilan Form Data Siswa}

Form ini digunakan pada saat penginputan data siswa

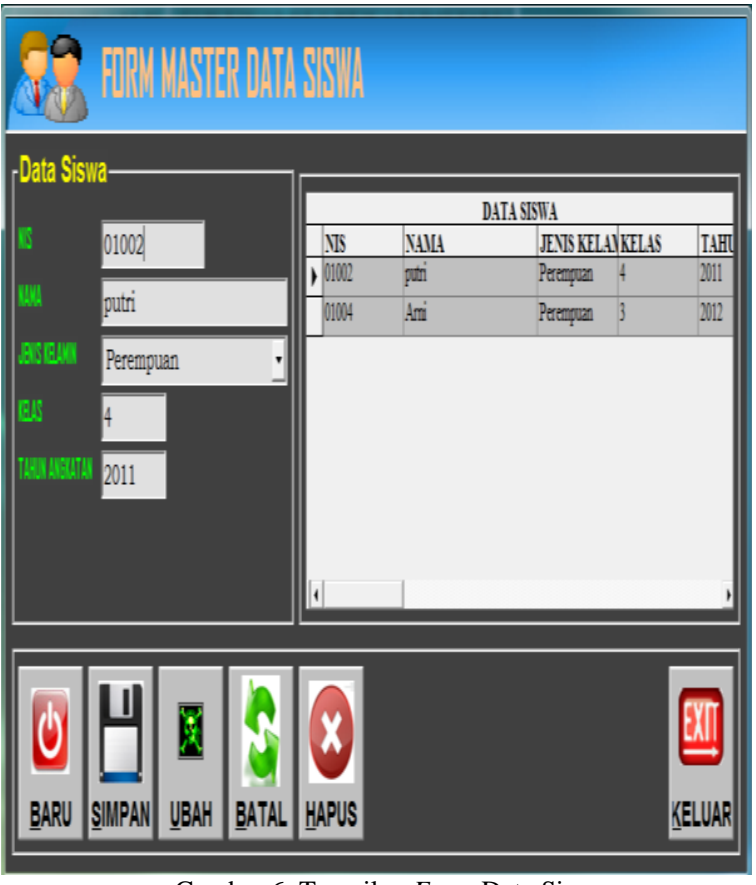

Gambar 6. Tampilan Form Data Siswa

4) Tampilan Form Data Siswa

Form ini dgunakan untuk menginput mata pelajaran

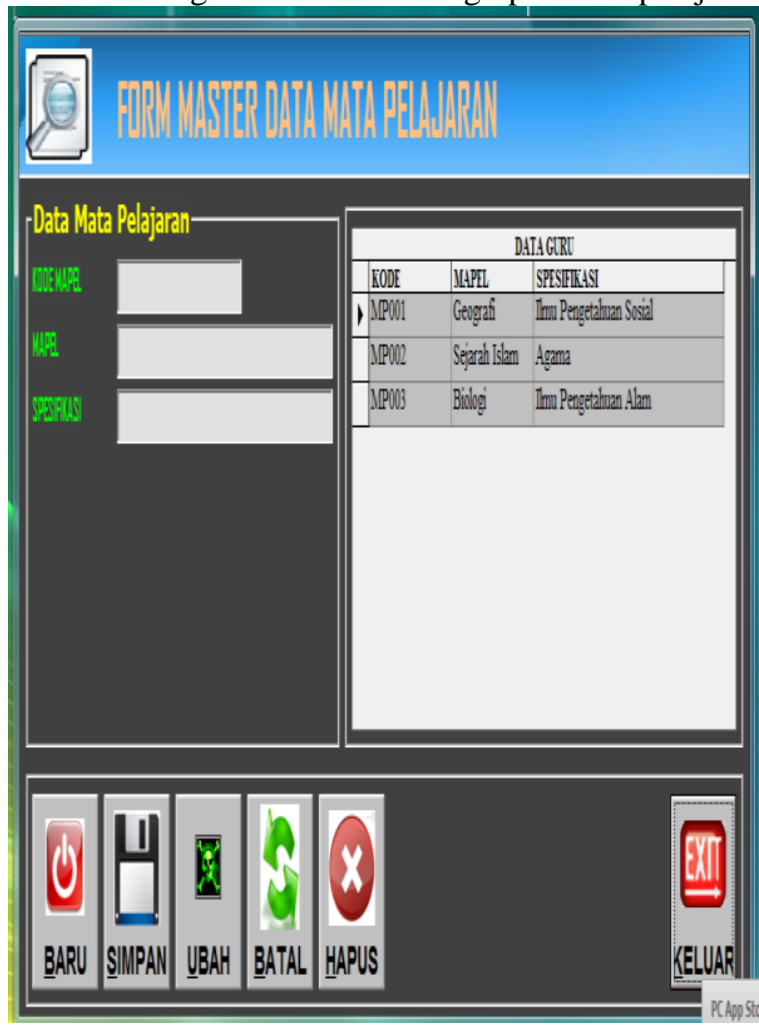

Gambar 7.Tampilan Form Data Pelajaran

\section{5) Tampilan Form Data Guru}

Form ini digunakan pada saat pencarian data guru 


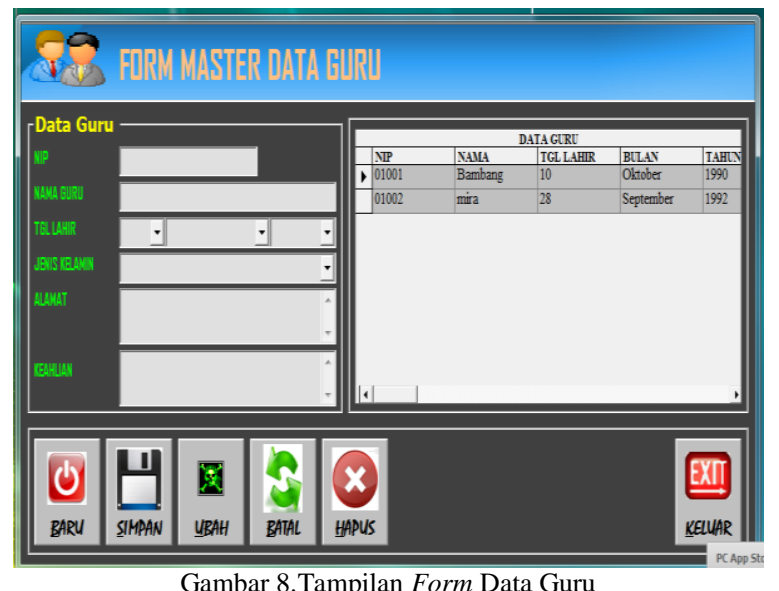

Gambar 8.Tampilan Form Data Guru

\section{6) Tampilan Form Data Guru}

Form ini digunakan untuk melakukan pencarian data mata pelajaran.

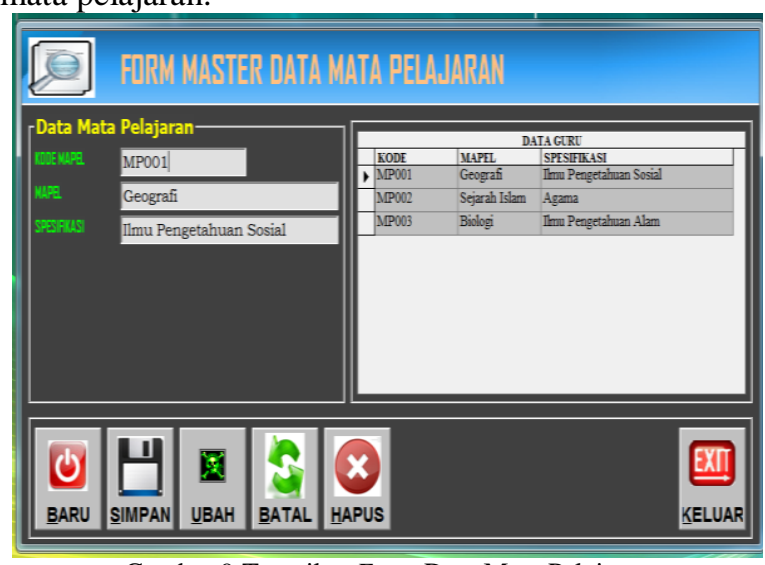

Gambar 9.Tampilan Form Data Mata Pelajaran

\section{7) Tampilan Form Jadwal Pelajaran}

Form ini digunakan untuk melakukan pencarian jadwal mata pelajaran.

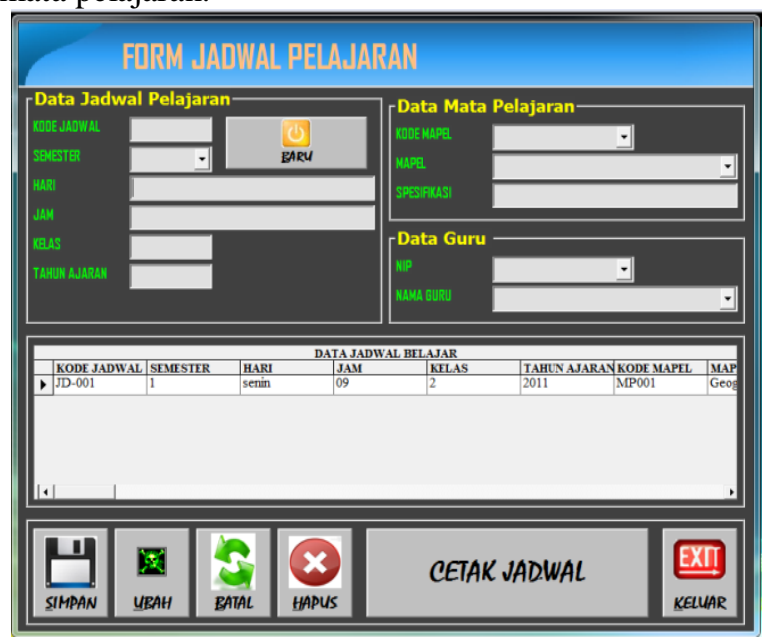

Gambar 10. Tampilan Form Jadwal Pelajaran

\section{8) Tampilan Form Cetak Jadwal Pelajaran}

Form ini digunakan untuk mencetak jadwal belajar

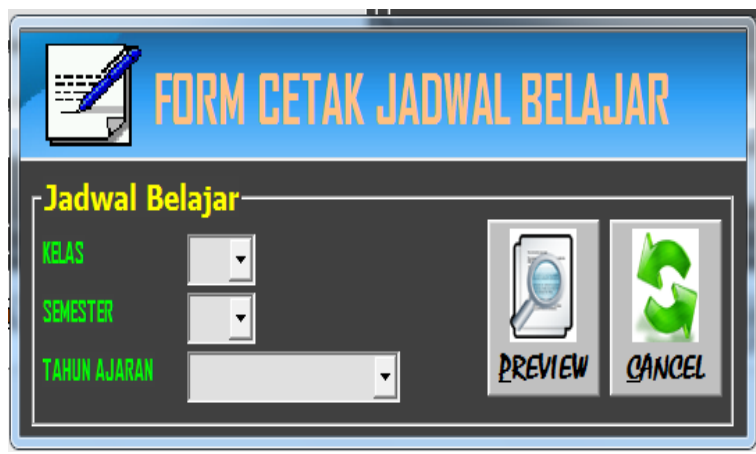

Gambar 11 Tampilan Form Cetak Jadwal Pelajaran

9) Tampilan Form Input Nilai

Form ini digunakan untuk mengisi data nilai siswa

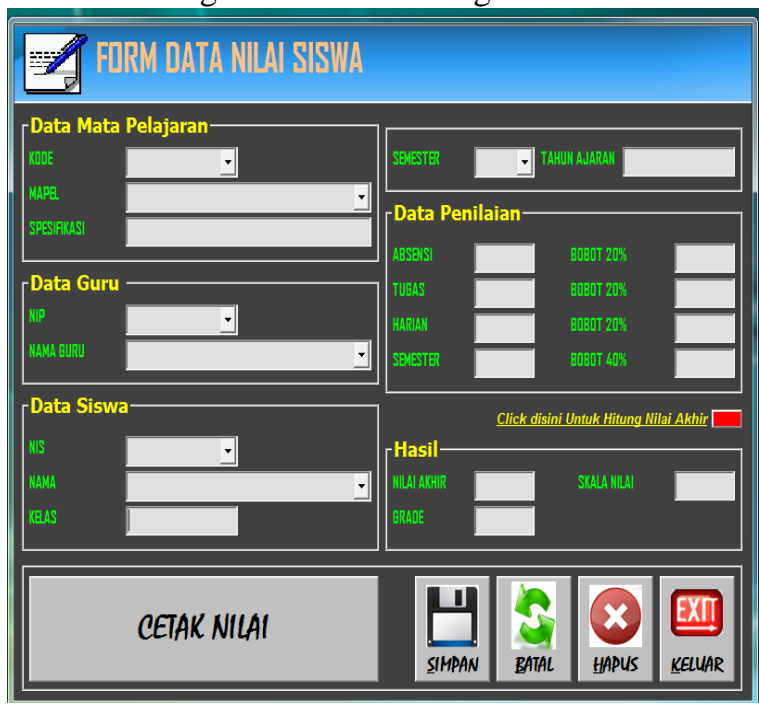

Gambar 12. Tampilan Form Input Nilai

10) Tampilan Form Cetak Nilai

Form ini digunakan untuk mencetak nilai siswa

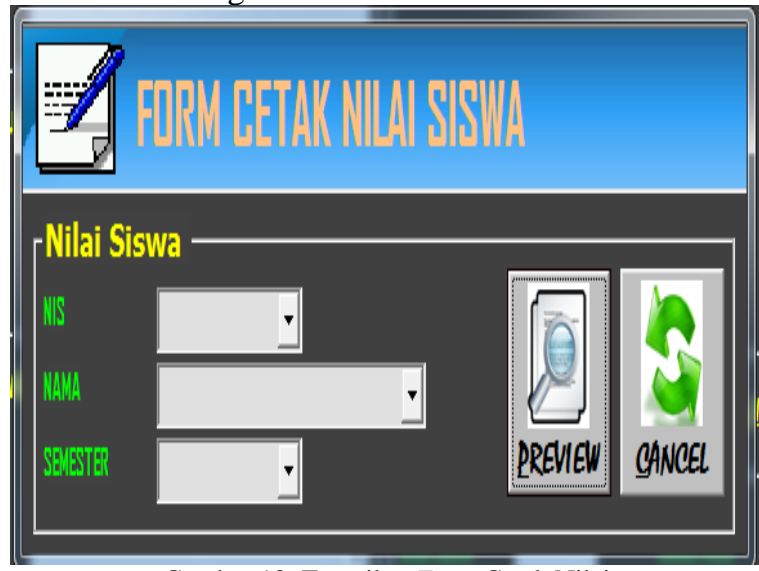

Gambar 13. Tampilan Form Cetak Nilai

11) Tampilan Form Cetak Laporan Nilai

Form ini digunakan untuk mencetak laporan nilai siswa persemester. 


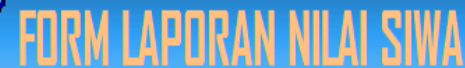

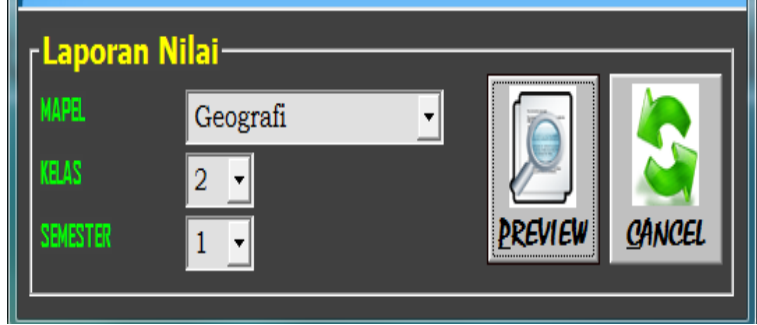

Gambar 14 Tampilan Form Cetak Laporan Nilai

\section{PENUTUP}

\section{A. Kesimpulan}

Berdasarkan pembahasan yang telah dikemukakan pada bab sebelumnya dalam penelitian penelitianini, maka peneliti mengambil kesimpulan, yaitu :

- Dengan menggunakan aplikasi yang diusulkan, maka dapat meningkatkan efisiensi kerja pada pegawai/guru. Misalnya dapat melakukan perubahan (update) data secara cepat pada saat dibutuhkan.

- Dengan menggunakan bahasa pemograman visual basic ini kita dapat membuat suatu program yang lebih menarik dan mempunyai fasilitas-fasilitas yang cukup memadai dalam menyelesaikan suatu program yang kita buat.

\section{B. Saran}

Adapun saran-saran dari peneliti akan disampaikan, yaitu:

- Dengan adanya aplikasi data nilai siswa ini diharapkan dapat membantu lembaga dalam mempercepat rekap hasil nilai siswa..

- Pembuatan terhadap backup file-file yang penting bagi lembaga sebaiknya dilakukan setiap akhir bulan mengingat perkembangan zaman yang semakin hari semakin berkembang terutama dibidang teknologi yang membantu aktivitas disegala bidang terutama bidang pendidikan, sebaiknya sekolah jangan sampai ketinggalan arus tehnologi tersebut dalam membantu pembangunan nasional.

\section{DAFTAR PUSTAKA}

[1] ANDI. (2010). Mahir dalam 7 Hari: Microsoft Visual Basic $6.0+$ Crystal Report 2008. Yogyakarta : ANDI OFFSET

[2] Fathansyah. (2012). Basis Data. Bandung : Informatika Bandung.

[3] Sutanta, Edhy. (2011). Basis Data dalam Tinjauan Konseptual. Yogyakarta: ANDI OFFSET.

[4] Nugroho, Adi. (2011). Perancangan dan Implementasi Sistem Basis Data. Bandung : ANDI. 